\title{
Characterization of Carcass Color Differences Between Hens (Small Birds) and Meat-Type Male Pheasants (Large Birds)
}

\author{
Ko-eun Hwang* and James R. Claus \\ Meat Science \& Animal Biologics Discovery, Department of Animal \& Dairy Sciences, University of Wisconsin-Madison, \\ Madison, WI 53706, USA \\ *Corresponding author. Email: khwang8@wisc.edu (Ko-eun Hwang)
}

\begin{abstract}
The underlying changes in hen carcass color upon freezing were compared with the color of meat-type male pheasants upon freezing. Chemical and physical assessments of these two pheasant types $(n=5)$ and the effects of different chilling methods on hen carcasses $(n=10)$ were evaluated. The results showed that hen carcasses exhibited more red pigmentation (myoglobin, hemoglobin), as well as significantly higher $\mathrm{pH}$ values and redness, than the carcasses from meat-type pheasants. The moisture content was higher in hens than in meat-type pheasants, especially in the skin. The intermediate fiber (IIA) type was the only type found in the pectoralis major muscle, regardless of pheasant type. Chilling method significantly changed the color attributes of the hen carcass. Immersion chilling decreased skin redness (less pigmentation and Commission Internationale de $1^{\prime}$ Eclairage [CIE] $a^{*}$ ); the breast meat was less red than that from the chilling-in-a-bag condition. The skin had substantially higher levels of red pigmentation than the breast muscles, irrespective of the pheasant type and chilling method $(P<0.05)$. Our findings suggest that the more intense red appearance may be related to a combination of greater residual hemoglobin levels and higher $\mathrm{pH}$ within the skin. The greater moisture content of the skin may have facilitated the development of greater transparency to the darker, more red breast muscle.
\end{abstract}

Key words: carcass quality, darker red appearance, meat pigments, skin color, chilling, freezing

Meat and Muscle Biology 5(1): 30, 1-9 (2021) doi:10.22175/mmb.11589

Submitted 24 July $2020 \quad$ Accepted 13 April 2021

\section{Introduction}

Color and appearance are common variables that influence consumers' decisions in buying meat. The changes in the color associated with the muscle and blood pigments (myoglobin [Mb] and hemoglobin $[\mathrm{Hb}]$, respectively) determine the freshness and quality of meat to some extent. Thus, color plays an important role in the acceptability of meat and poultry (Mancini and Hunt, 2005; Suman and Joseph, 2013).

$\mathrm{Mb}$ is the primary meat pigment that imparts red color to a well-bled livestock carcass (Wittenberg and Wittenberg, 2003). The different colors of meat reflect the amount of $\mathrm{Mb}$ present in the muscle, which is indicative of the muscle's physical activity. Heavily used muscles contain higher Mb levels than infrequently used muscles. In turkeys and chickens that walk around a lot but rarely fly, the leg meat is dark, whereas the breast meat is much lighter. In contrast, game birds (such as pheasants, geese, and ducks) tend to have darker breast meat than domesticated animals (Stoker, 2013).

Previously published studies have postulated that the factors that influence poultry meat and skin color include live production practices, slaughter processing, handling, chilling method, freezing rate, and packaging technology (Fletcher, 1989; Petracci and Fletcher, 2002; Wideman et al., 2016; Mir et al., 2017). Regarding chilling systems for poultry processing, air chilling (characterized as having no moisture pickup or negative yield due to excessive moisture loss and consequent weight loss between $1 \%$ and $1.5 \%$ ) causes 
surface dehydration and discoloration. On the contrary, poultry carcasses may absorb $4 \%$ to $6 \%$ water through the skin during immersion chilling, facilitating the migration of water-soluble proteins $(\mathrm{Mb}, \mathrm{Hb}$, and cytochrome C) to the surface (Jeong et al., 2011). Immersion chilling, therefore, improves the color and appearance of poultry carcasses (Demirok et al., 2013).

Pheasants (Phasianus colchicus) have been widely introduced as one of the oldest game bird species and have been primarily reared for use on hunting preserves. More recently, the demand for pheasant meat has steadily increased because of its nutritional quality-pheasant meat has more protein and less fat in breast and thigh muscles compared with chicken meat (Ve erek et al., 2005; Straková et al., 2011; Franco and Lorenzo, 2013). However, meat quality characteristics in pheasant have not been well studied. The majority of the available literature is associated with the effect of age and sex at slaughter and the chemical composition of pheasant meat (Ve erek et al., 2005; Straková et al., 2011; Kotowicz et al., 2012).

Meat quality properties of pheasants depend on their age, sex, and breeding conditions (Kotowicz et al., 2012). According to pheasant industry technical personnel, between pheasant types, hen pheasant carcasses (small birds) appear to have more visible red pigmentation on the outer surface than the carcasses of meat-type male pheasants (large birds). Hen carcasses become visibly more red upon freezing. Therefore, 2 objectives of this study included characterization of the color differences associated with pheasant type (small birds [hens] versus large meat-type pheasants [males]) and determination of the effects of the chilling method (chilling-in-abag $[\mathrm{CB}]$ or direct immersion chilling in water [CW]) related to frozen hen carcasses.

\section{Materials and Methods}

\section{Slaughter and sample collection}

Two independent experiments were undertaken. Hens and meat-type male pheasants were fed a proprietary all-vegetable diet (corn, soy, and wheat; supplemented with vitamins and minerals; MacFarlane Pheasants Inc., Janesville, WI). All pheasants were electrically knife stunned (set on \#4; model V5200; Midwest Processing System Inc., Eden Prairie, MN), bled $(\sim 40 \mathrm{~s})$, scalded $\left(55^{\circ} \mathrm{C}-60^{\circ} \mathrm{C} ; \sim 40 \mathrm{~s}\right)$, and defeathered using a rotary drum plucker at a commercial poultry processing facility. Pheasants were slaughtered in a different month for each experiment (Experiment 1 and
2; June and October, respectively). Hens were slaughtered at 14-15 wk of age (body weight: 794-1,021 g), and meat-type male pheasants were slaughtered at 12-13 wk of age (body weight: 1,134-1,361 g). In the first experiment, which addressed pheasant type, the frozen carcasses ( $n=5$ each pheasant type) in their original, sealed plastic bags were brought to the University of Wisconsin Meat Science Laboratory and stored in $\mathrm{a}-25^{\circ} \mathrm{C}$ freezer. In the second experiment, which evaluated chilling method effects ( $\mathrm{CB}$ or $\mathrm{CW}$ ), defeathered hen pheasant carcasses were individually shackled and manually eviscerated before entry into a water-chill tank. Once the carcasses entered the processing facility's water-chill tank, randomly selected carcasses ( $n=10$ each chilling method) were immediately removed. Carcasses assigned to $\mathrm{CW}$ were individually weighed, tagged, and placed in plastic coolers that were filled with a mixture of water and ice. Hen carcasses assigned to the CB method were individually weighed, tagged, and placed in a plastic bag (one carcass per bag), which was then sealed before placement into the plastic coolers. The initial chilling process was carried out in plastic coolers at around $4^{\circ} \mathrm{C}$ for $3 \mathrm{~h}$ using equal numbers of carcasses from each chilling method distributed into 2 coolers. Once carcasses were added to the coolers, more ice was added to maintain the temperature. Two digital thermometers/loggers were used to monitor the temperature in the coolers (average temperature of $3.5^{\circ} \mathrm{C}$ ) until the carcasses were transported to the University of Wisconsin Meat Science Laboratory. Upon arrival, the coolers with carcasses were moved to a walk-in cooler at $4^{\circ} \mathrm{C}$ for the remaining chilling period. After chilling, carcasses $(\mathrm{CB}, \mathrm{CW})$ were removed from the plastic coolers and placed in separate plastic lugs. The CB carcasses were removed from the bags. All carcasses were then allowed to drain for $5 \mathrm{~min}$ and weighed again after $24 \mathrm{~h}$ to obtain a post-chill weight. Color was evaluated instrumentally on the breast skin surface before each carcass was individually vacuum packaged in a Nylon/Polyethylene vacuum pouch. Vacuum-packaged carcasses were immediately boxed and stored in the cooler for about $2 \mathrm{~h}$ before being moved to the freezer $\left(-25^{\circ} \mathrm{C}\right)$. Carcasses remained in the freezer for $5 \mathrm{~d}$ (day 7 postmortem) before analysis.

\section{Chemical and physical methods}

Sample preparation. All frozen carcasses were semi-thawed for about $24 \mathrm{~h}\left(4^{\circ} \mathrm{C}\right)$ to excise the breast muscle while avoiding moisture loss. Breast muscles (M. pectoralis major) were collected, cut into similar 
sections (approximately $2.5 \mathrm{~cm} \times 2.5 \mathrm{~cm} \times 1.5 \mathrm{~cm}$ ), vacuum packaged in a Nylon/Polyethylene vacuum bag, and stored in a freezer $\left(-25^{\circ} \mathrm{C}\right)$. The frozen samples were ground ( $9.5 \mathrm{~mm}$ plate). Skins were trimmed of excessive fat before pulverization in liquid nitrogen, and the samples were stored at $-25^{\circ} \mathrm{C}$.

Instrumental color. Color was determined using a chroma meter (model CR-300; $8 \mathrm{~mm}$ aperture; Minolta Camera Co., Ltd., Osaka, Japan). The chroma meter was standardized against a white calibration plate (No. 18133019; $\mathrm{Y}=93.7, \mathrm{x}=0.3163, \mathrm{y}=0.3324$ ) contained within the test bag. Color readings were measured at 8 different locations (cranial, medial, and caudal) on the surface of the breast skin and breast muscle on each semi-frozen pheasant carcass. The collected data were averaged for the statistical analysis.

pH. The $\mathrm{pH}$ of 5-g samples blended with $50 \mathrm{~mL}$ of distilled water with a homogenizer (model Polytron PT 10-35 GT; Kinematica AG, Luzern, Switzerland) for $60 \mathrm{~s}$ was determined with a $\mathrm{pH}$ meter (model Accumet AB15 Plus; Fisher Scientific, Waltham, MA). Three different standard solutions $(\mathrm{pH} 4.0, \mathrm{pH} \mathrm{7.0,} \mathrm{and}$ pH 10.0 buffers; Fisher Scientific) maintained at room temperature $\left(25^{\circ} \mathrm{C}\right)$ were used to calibrate the $\mathrm{pH}$ meter.

Moisture and protein content. Moisture content of samples was determined in duplicate by drying the samples in a laboratory oven (model Imperial V; Lab-line Instruments Inc., Melrose Park, IL) at $105^{\circ} \mathrm{C}$ for $24 \mathrm{~h}$ (method 934.01; AOAC, 2005). The protein content of samples was evaluated using a rapid protein analyzer (model CEM Sprint rapid protein analyzer; CEM Corporation, Matthews, NC) according to the AOAC Official Method for Protein in Raw and Processed Meats (method 2011.04; AOAC, 2011).

Total pigment. Total pigment (undenatured $\mathrm{Mb}$ and residual $\mathrm{Hb}$ ) was extracted from the raw pheasant breast muscle and skin using the procedure described by Warris (1979). Total pigment content (in duplicate, approximately $5 \mathrm{~g}$ each) was calculated based on the absorbance of the clarified extract at $525 \mathrm{~nm}$ wavelength using an ultraviolet-visible spectrophotometer (model UV-2501; Shimadzu Corporation, Kyoto, Japan). Total pigment $(\mathrm{Mb} / \mathrm{Hb})$ content was calculated using the following formula (Faustman and Phillips, 2001): $\mathrm{Mb} / \mathrm{Hb}(\mathrm{mg} / \mathrm{g})=(\mathrm{A} 525 / 7.6) \times 17 \times 6$.

Muscle fiber type. Serial cross-sections of $10 \mu \mathrm{m}$ thickness were cut with a cryostat (model Microtome cryostat HM 505 N; MICROM, Walldorf, Germany) at $-24^{\circ} \mathrm{C}$. The fibers were stained with azorubine to delineate their outline. Fiber contractile type was determined by evaluating myofibrillar ATPase activity after incubation in both acid $(\mathrm{pH} 4.6)$ and alkali $(\mathrm{pH}$ 10.3) buffers (Brooke and Kaiser, 1970; Lind and Kernell, 1991). Histochemical images were photographically captured using a microscope smartphone camera adaptor (Roy et al., 2014) mounted on a microscope (model Motic BA410; Motic Incorporation Ltd, Xiamen, China) and examined using a public domain image analysis software (ImageJ version 1.53a; National Institutes of Health, Bethesda, MD; https:// imagej.nih.gov.ij).

\section{Statistical analysis}

For the statistical analysis, animal served as the experimental unit (random effect). A $2 \times 2$ factorial design was used to analyze the main effects of pheasant type (hen or meat-type) and carcass component (breast [lean] or carcass skin) and their interactions on $\mathrm{pH}$, moisture, protein, and total pigments. A $2 \times 3$ factorial design was used to analyze the main effects of the chilling method $(\mathrm{CB}, \mathrm{CW})$ and breast parameter (unfrozen breast skin surface, semi-thawed breast skin surface, semi-thawed breast surface without skin) and their interactions on color data. Chilling method as the main effect was used to analyze the color data (CIE $L^{*}, a^{*}$, and $b^{*}$, total pigment). A $2 \times 2$ factorial design was used to analyze the main effects of chilling method and carcass component and their interactions on $\mathrm{pH}$ and pigment content. The SAS MIXED procedure (SAS version 9.1.3 Service Pack 3; SAS Institute Inc., Cary, NC) was used to determine significance $(P<0.05)$ in the model. When significance was found, means were separated using the Least Significant Difference method. Letter assignment to individual means to enable statistical comparisons was achieved using the pdmix800 macro (Saxton, 1998).

\section{Results}

\section{Experiment 1: Evaluation of color differences between hens and meat-type pheasants}

Visually, frozen hen pheasant appeared darker and more red than meat-type male pheasant carcasses (Figure 1). The different chemical and physical assessments (Table 2) between hens and meat-type pheasants revealed that hens exhibited greater redness (CIE $a^{*}$ : 4.9 vs. $4.3 ; P<0.05)$ values and were darker (CIE $L^{*}: 53.3$ vs. $\left.55.7 ; P<0.05\right)$ than the meat-type 

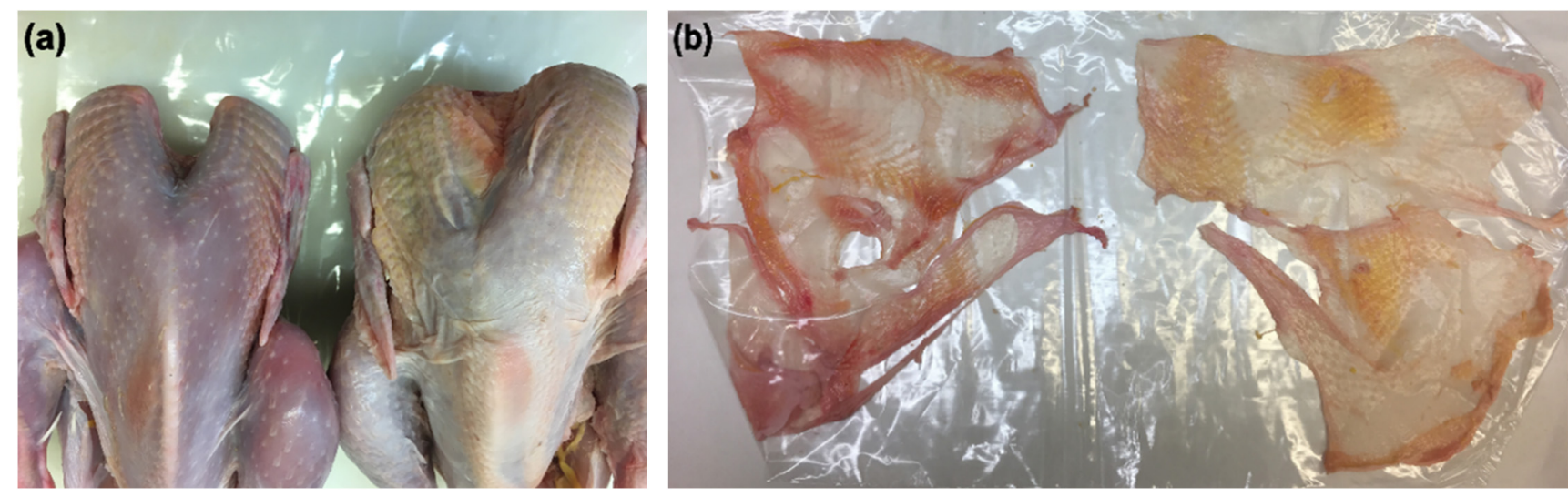

Figure 1. Visible differences between hen (left) and the meat-type (right) pheasant types. (a) Frozen/semi-thawed whole pheasant carcasses. (b) Frozen/ semi-thawed pheasant skins.

Table 1. Type 3 tests of fixed effects associated with pheasant type, chilling method, carcass composition, and parameter on various dependent variables ${ }^{1}$

\begin{tabular}{|c|c|c|c|c|c|c|c|c|}
\hline Independent Variables ${ }^{2}$ & CIE $L^{*}$ & $\mathrm{CIE} a^{*}$ & $\mathrm{CIE} b^{*}$ & $\mathrm{pH}$ & $\begin{array}{c}\text { Total Pigment } \\
\text { (mg/g meat) }\end{array}$ & Moisture (\%) & Protein $(\%)$ & $\begin{array}{c}\text { Weight } \\
\text { Change (\%) }\end{array}$ \\
\hline \multicolumn{9}{|l|}{ Experiment 1} \\
\hline PT & 0.023 & 0.016 & 0.076 & $<0.0001$ & $<0.0001$ & $<0.0001$ & 0.004 & - \\
\hline $\mathrm{CC}$ & - & - & - & $<0.0001$ & $<0.0001$ & $<0.0001$ & $<0.0001$ & - \\
\hline $\mathrm{PT} * \mathrm{CC}$ & - & - & - & $<0.0001$ & $<0.0001$ & $<0.0001$ & $<0.0001$ & - \\
\hline \multicolumn{9}{|l|}{ Experiment 2} \\
\hline $\mathrm{CM}$ & 0.000 & $<0.0001$ & 0.000 & 0.838 & $<0.0001$ & - & - & $<0.0001$ \\
\hline $\mathrm{CC}$ & - & - & - & $<0.0001$ & $<0.0001$ & - & - & - \\
\hline $\mathrm{CM} * \mathrm{CC}$ & - & - & - & 0.488 & $<0.0001$ & - & - & - \\
\hline $\mathrm{P}$ & $<0.0001$ & $<0.0001$ & 0.001 & - & - & - & - & - \\
\hline $\mathrm{CM} * \mathrm{P}$ & $<0.0001$ & 0.734 & 0.234 & - & - & - & - & - \\
\hline
\end{tabular}

${ }^{1}$ Dependent variables: CIE $L^{*}$ (lightness), CIE $a^{*}$ (redness), CIE $b^{*}$ (yellowness), pH, total pigments (mg/g meat), moisture (\%), protein (\%), weight change (g).

${ }^{2}$ Independent variables: pheasant type $(\mathrm{PT})=$ hen, meat-type; carcass composition $(\mathrm{CC})=$ breast lean, skin; chilling method $(\mathrm{CM})=\mathrm{CB}$ : chilling-in-a-bag, $\mathrm{CW}$ : immersion chilling in water; parameter $(\mathrm{P})=$ unfrozen breast skin surface, semi-thawed breast skin surface, semi-thawed breast surface without skin

Table 2. Color characteristics of frozen/semi-thawed breast muscles on hen and meat-type pheasant types $(n=5)$

\begin{tabular}{|c|c|c|c|}
\hline \multirow[b]{2}{*}{ Dependent Variables $^{1}$} & \multicolumn{2}{|c|}{ Breast Muscle } & \multirow[b]{2}{*}{ Standard Erro } \\
\hline & Hen & Meat-Type & \\
\hline $\operatorname{CIE} L^{*}$ & $53.3^{\mathrm{b}}$ & $55.7^{\mathrm{a}}$ & 0.731 \\
\hline $\operatorname{CIE} a^{*}$ & $4.9^{\mathrm{a}}$ & $4.3^{\mathrm{b}}$ & 0.111 \\
\hline CIE $b^{*}$ & $1.3^{\mathrm{a}}$ & $2.1^{\mathrm{a}}$ & 0.402 \\
\hline
\end{tabular}

${ }^{1}$ Dependent variable: CIE $L^{*}$ (lightness), CIE $a^{*}$ (redness), CIE $b^{*}$ (yellowness); higher $L^{*}, a^{*}$, and $b^{*}$ values relate to lighter, redder, and yellower breast muscles, respectively.

${ }^{\mathrm{a}, \mathrm{b}}$ Means within a row with unlike superscript letters are different $(P<0.05)$.

pheasants on frozen/semi-thawed breast. No difference was observed in yellowness (CIE $b^{*}$ ) between the different pheasant types $(P>0.05)$.
The highest $\mathrm{pH}$ and pigment content $(\mathrm{Mb}$ and $\mathrm{Hb})$ values were determined for the skin from hen carcasses as compared with the skin from the meat-type pheasants (Table 3). Furthermore, the breast muscle of hens had a higher $\mathrm{pH}$ and pigment content than that of meattype pheasants $(P<0.05)$. Kotowicz et al. (2012) reported a $\mathrm{pH}$ value of 5.64 for the breast muscle of hen pheasants, which is consistent with the present study's result. Choi et al. (2016) observed that chicken skin had a higher $\mathrm{pH}(\mathrm{pH}$ 6.22) than chicken breast muscle ( $\mathrm{pH}$ 5.99).

The moisture content of the breast muscles from hen carcasses was greater $(P<0.05)$ than that of the meat-type pheasants (Table 3 ). However, the protein content was not different $(P>0.05)$ between the pheasant types. Similar observations were reported in hen pheasants (Hofbauer et al., 2010; Kotowicz et al., 2012), 
Table 3. Meat quality characteristics of frozen/semithawed breast muscle and skin on hen and meat-type pheasant types $(n=5)$

\begin{tabular}{|c|c|c|c|c|c|}
\hline \multirow[b]{2}{*}{$\begin{array}{l}\text { Dependent } \\
\text { Variables }^{1}\end{array}$} & \multicolumn{2}{|c|}{ Breast Muscle } & \multicolumn{2}{|c|}{ Skin } & \multirow[b]{2}{*}{$\begin{array}{c}\text { Standard } \\
\text { Error }\end{array}$} \\
\hline & Hen & $\begin{array}{l}\text { Meat- } \\
\text { Type }\end{array}$ & Hen & $\begin{array}{l}\text { Meat- } \\
\text { Type }\end{array}$ & \\
\hline $\mathrm{pH}$ & $5.9^{\mathrm{c}}$ & $5.8^{\mathrm{d}}$ & $6.4^{\mathrm{a}}$ & $6.21^{\mathrm{b}}$ & 0.008 \\
\hline $\begin{array}{l}\text { Myoglobin } \\
\text { (mg/g meat) }\end{array}$ & $1.5^{\mathrm{b}}$ & $1.0^{\mathrm{d}}$ & $1.89^{\mathrm{a}}$ & $1.2^{\mathrm{c}}$ & 0.017 \\
\hline Moisture (\%) & $75.0^{\mathrm{a}}$ & $74.5^{\mathrm{b}}$ & $74.27^{\mathrm{b}}$ & $60.2^{\mathrm{c}}$ & 0.128 \\
\hline Protein (\%) & $24.9^{\mathrm{a}}$ & $25.5^{\mathrm{a}}$ & $13.43^{\mathrm{b}}$ & $10.9^{\mathrm{c}}$ & 0.268 \\
\hline
\end{tabular}

${ }^{1}$ Dependent variable: myoglobin analysis method includes residual hemoglobin.

${ }^{\mathrm{a}-\mathrm{d}}$ Means within a row with unlike superscript letters are different $(P<0.05)$

wherein the moisture, protein, and fat contents of the breast muscles ranged from about $71.8 \%$ to $73.1 \%$, $21.9 \%$ to $25.3 \%$, and $0.52 \%$ to $2.16 \%$, respectively. In addition, the skin from meat-type pheasants contained less moisture and protein content (Table 3 ) than the skin from hen carcasses.

No differences were observed in the muscle fiber types between hen and meat-type pheasants in the present study. The IIA fiber type was observed only in pectoralis major muscle, regardless of pheasant type (Figure 2). Our results are similar to those reported in game birds that often fly and have darker breast meat than domestic birds, which rarely fly (Stoker, 2013). Some previous studies have found that the majority of pectoralis of flight birds is predominantly composed of IIA fibers, irrespective of the animal's flight ability, whereas nonflying bird species have pectoralis muscles with a comparatively higher level of white fibers (type IIB; Libera and Carpene, 1997; Welch and Altshuler, 2009).

\section{Experiment 2: Evaluation of the effects of $C B$ versus $C W$ on hen carcasses}

Chilling methods markedly affected the color attributes of hen carcasses. After chilling, CB carcasses lost $-0.46 \%$ of their weight (Table 4 ) and consequently had a higher redness value on the breast skin surface (Table 5). On the contrary, the carcasses from the CW group absorbed moisture equivalent to $3.32 \%$ of their weight, resulting in an increase in the lightness of the breast skin surface. After freezing, the CIE $L^{*}$ values

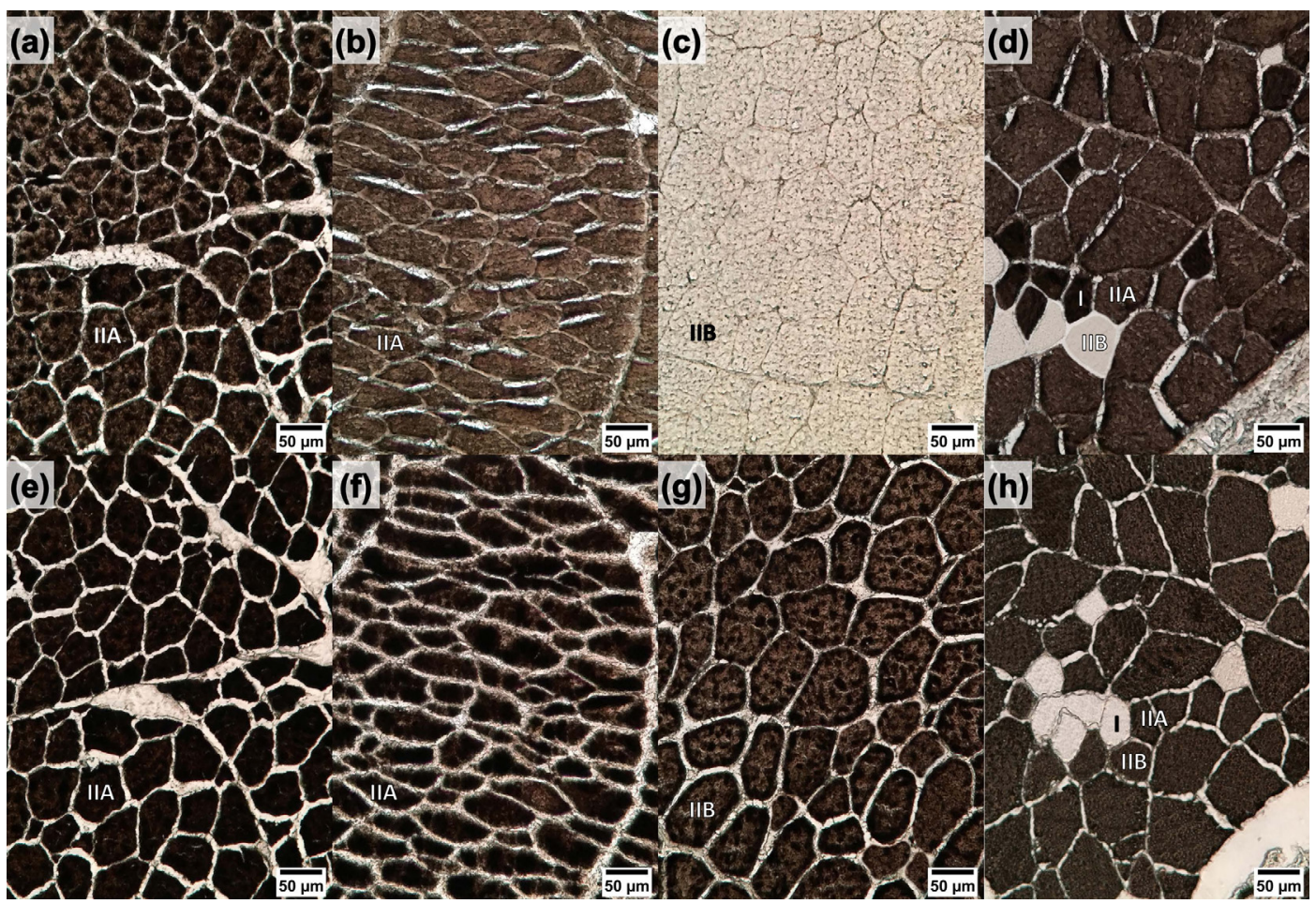

Figure 2. Muscle fiber cross-sections in pectoralis major muscles between hen and meat-type pheasant types. Magnification of $200 \times$ was used (bar $=50 \mu \mathrm{m})$. Chicken and pork meat were used as references. The images of muscle sections were captured from differently stained serial sections. (a) Hen, (b) Meat-type, (c) Chicken, and (d) Pork, myosin ATPase at pH 4.6; (e) Hen, (f) Meat-type, (g) Chicken, and (h) Pork, myosin ATPase at pH 10.3. I = type I or red fiber; IIA = type IIA or intermediate fiber; IIB = type IIB or white fiber. 
Table 4. Weight changes of hen carcasses during different chilling methods ${ }^{1}(n=10)$

\begin{tabular}{lcc}
\hline \hline & \multicolumn{2}{c}{ Chilling Method } \\
\cline { 2 - 3 } Parameters $^{2}$ & $\mathrm{CB}$ & $\mathrm{CW}$ \\
\hline Before chilling $(\mathrm{g})$ & 844.5 & 899.0 \\
After chilling for 3 h $(\mathrm{g})$ & 841.1 & 959.4 \\
After cooling for 24 h (g) & 840.7 & 930.3 \\
Weight change $(\mathrm{g})$ & $-3.8^{\mathrm{b}}$ & $31.2^{\mathrm{a}}$ \\
Weight change $(\%)$ & $-0.5^{\mathrm{b}}$ & $3.3^{\mathrm{a}}$ \\
\hline
\end{tabular}

${ }^{1}$ Chilling method: $\mathrm{CB}$ : chilling-in-a-bag; CW: immersion chilling in water.

${ }^{2}$ Weight change (g) of carcass as a result of the chilling method: after cooling - before chilling; weight change (\%) of carcass as a result of the chilling method: (after cooling $24 \mathrm{~h}$-before chilling) $\div$ before chilling $\times 100$.

${ }^{\mathrm{a}, \mathrm{b}}$ Means within a row with unlike superscript letters are different $(P<0.05)$

Standard error: weight change (grams) (2.29), weight change (percentage) (2.77) of the breast skin surface from the frozen/semi-thawed $\mathrm{CB}$ and $\mathrm{CW}$ groups substantially decreased compared with the values found on the unfrozen breast skin surface $(P<0.05)$. Regardless of chilling methods, removing the skin resulted in a darker color.

No significant differences in $\mathrm{pH}$ values were observed for the breast muscles or skin, irrespective of chilling method $(P>0.05)$. Immersion chilling caused a noticeable decrease in $\mathrm{Mb} / \mathrm{Hb}$ level in the skin of hen carcasses $(P<0.05$; Table 6$)$. Water absorption during $\mathrm{CW}$ may be responsible for light scattering and intense lightness. In addition, the decrease in red color was likely related to the removal of water-soluble proteins $(\mathrm{Mb}, \mathrm{Hb}$, and cytochrome C; Huezo et al., 2007; Sams and Mckee, 2010).

\section{Discussion}

There are obvious differences in the muscle fiber types (type I or red fiber; type IIA or intermediate fiber;

Table 5. Effect of chilling method ${ }^{1}$ on color characteristics ${ }^{2}$ on hen carcasses $(n=10)$

\begin{tabular}{|c|c|c|c|c|c|c|c|c|c|}
\hline \multirow[b]{2}{*}{ Parameters } & \multicolumn{3}{|c|}{ CIE $L^{*}$} & \multicolumn{3}{|c|}{$\operatorname{CIE} a^{*}$} & \multicolumn{3}{|c|}{$\mathrm{CIE} b^{*}$} \\
\hline & $\mathrm{CB}$ & $\mathrm{CW}$ & $\begin{array}{c}\text { Overall Chilling } \\
\text { Method }\end{array}$ & $\mathrm{CB}$ & $\mathrm{CW}$ & $\begin{array}{l}\text { Overall Chilling } \\
\text { Method }\end{array}$ & $\mathrm{CB}$ & $\mathrm{CW}$ & $\begin{array}{l}\text { Overall Chilling } \\
\text { Method }\end{array}$ \\
\hline \multicolumn{10}{|l|}{ Unfrozen (never frozen) } \\
\hline Breast skin surface & $68.1^{\mathrm{b}}$ & $72.1^{\mathrm{a}}$ & 70.1 & 5.2 & 4.2 & $4.7^{\mathrm{y}}$ & 0.4 & 1.5 & $1.0^{\mathrm{x}}$ \\
\hline \multicolumn{10}{|l|}{ Frozen/semi-thawed } \\
\hline Breast skin surface & $60.3^{\mathrm{c}}$ & $60.4^{\mathrm{c}}$ & 60.3 & 5.2 & 4.0 & $4.6^{\mathrm{y}}$ & -0.6 & 1.1 & $0.2^{\mathrm{y}}$ \\
\hline Breast surface without skin & $51.2^{\mathrm{d}}$ & $50.9^{\mathrm{d}}$ & 51.0 & 6.0 & 5.1 & $5.5^{\mathrm{x}}$ & 1.3 & 1.7 & $1.5^{\mathrm{x}}$ \\
\hline Overall parameter & 59.8 & 61.1 & & $5.5^{\mathrm{a}}$ & $4.4^{\mathrm{b}}$ & & $0.4^{\mathrm{b}}$ & $1.4^{\mathrm{a}}$ & \\
\hline
\end{tabular}

${ }^{1}$ Chilling method: $\mathrm{CB}$ : chilling-in-a-bag; $\mathrm{CW}$ : immersion chilling in water.

${ }^{2}$ Color measurements: CIE $L^{*}$ (lightness), CIE $a^{*}$ (redness), CIE $b^{*}$ (yellowness); higher $L^{*}, a^{*}$, and $b^{*}$ values relate to lighter, redder, and yellower breast muscles, respectively.

${ }^{\mathrm{a}-\mathrm{d}}$ Means within a column with unlike superscript letters are different $(P<0.05)$. Standard error (SE): CIE $L^{*}(0.40)$.

${ }^{\mathrm{a}, \mathrm{b}}$ Overall parameters: means within a row with unlike superscript letters are different $(P<0.05)$. SE: CIE $a^{*}(0.11)$; CIE $b^{*}(0.31)$.

${ }^{\mathrm{x}, \mathrm{y}}$ Overall chilling method: means within a column with unlike superscript letters are different $(P<0.05)$. SE: CIE $a^{*}(0.14)$; CIE $b^{*}(0.34)$.

Table 6. Effect of chilling method ${ }^{1}$ on $\mathrm{pH}$ values and myoglobin concentrations on breast muscle and skin of hen carcasses $(n=10)$

\begin{tabular}{|c|c|c|c|c|c|c|}
\hline \multirow[b]{2}{*}{ Dependent Variables ${ }^{2}$} & \multicolumn{3}{|c|}{ Breast Muscle } & \multicolumn{3}{|c|}{ Skin } \\
\hline & $\mathrm{CB}$ & $\mathrm{CW}$ & $\begin{array}{c}\text { Overall Chilling } \\
\text { Method }\end{array}$ & $\mathrm{CB}$ & $\mathrm{CW}$ & $\begin{array}{c}\text { Overall Chilling } \\
\text { Method }\end{array}$ \\
\hline $\mathrm{pH}$ & 5.7 & 5.8 & $5.8^{\mathrm{y}}$ & 6.2 & 6.2 & $6.2^{\mathrm{x}}$ \\
\hline Myoglobin (mg/g meat) & $1.1^{\mathrm{c}}$ & $1.1^{\mathrm{c}}$ & 1.1 & $2.2^{\mathrm{a}}$ & $1.5^{\mathrm{b}}$ & 1.8 \\
\hline
\end{tabular}

${ }^{1}$ Chilling method: $\mathrm{CB}$ : chilling-in-a-bag; CW: immersion chilling in water.

${ }^{2}$ Dependent variables: myoglobin analysis method includes residual hemoglobin.

${ }^{\mathrm{a}-\mathrm{C}}$ Means within a row with unlike superscript letters are different $(P<0.05)$. Standard error $(\mathrm{SE})$ : myoglobin $(0.05)$.

${ }^{\mathrm{x}, \mathrm{y}}$ Overall chilling method: means within a row with unlike superscript letters are different $(P<0.05)$. SE: $\mathrm{pH}(0.02)$. 
type IIB or white fiber) between the pectoralis major muscle of nonflying birds and game birds. In general, nonflying birds such as chicken have pectoralis muscles with high concentrations of type IIB fibers (Welch and Altshuler, 2009). In contrast, game birds such as pheasants and ducks have pectoralis major muscle that is mainly composed of oxidative muscles (type I and IIA) owing to the high content of $\mathrm{Mb}$, which imparts a red color to the muscle (Stoker, 2013). Interestingly, the muscle fiber type between hens and meat-type pheasants did not appear to be different in our study. However, it is unknown whether there has been a muscle fiber type shift from native, wild game bird pheasants. It should be noted that the $\mathrm{Mb}$ method used does not distinguish between $\mathrm{Mb}$ and $\mathrm{Hb}$, and as such, perhaps this would help clarify the greater pigmentation in the hens.

Chilling methods significantly affected the color attributes of the hen carcass. Similar results were reported in a previous poultry chilling study (Jeong et al., 2011) that compared the effects of water chilling, air chilling, and evaporated air chilling on the surface color of broiler carcasses. Water-chilled carcasses exhibited higher lightness values on the skin surface for 5 areas (breast, wing, thigh, drumstick, and scapula) than air-chilled or evaporated-air-chilled carcasses. Huezo et al. (2007) indicated that water-chilled carcasses had lower redness values on the breast skin surface than air-chilled carcasses, wherein the skin turned more translucent after cooling and became darker as the underlying muscle became visible through the skin. Petracci and Fletcher (2002) found that, during the first $4 \mathrm{~h}$ from slaughter to processing, broiler meat and skin color dramatically changed while the carcasses were still in the processing plant. After $4 \mathrm{~h}$, the color continued to alter but at a slower rate up to 12 to $24 \mathrm{~h}$ postmortem. These authors suggested that broiler skin and meat color changes that occur during storage (from 1 to $8 \mathrm{~d}$ postmortem) were variable and relied on processing or holding conditions. Thus, total immersion chilling time and temperature may play a role in redness.

In summary, these 2 independent experiments provide the opportunity for additional discussion on the potential mechanisms involved. The hen skin appeared more red and exhibited considerably higher $\mathrm{pH}$ and a greater level of red pigmentation than the breast muscles examined, irrespective of pheasant type and chilling method. Several conditions may have contributed to these outcomes.

A first hypothesis is associated with the stress prior to slaughter because a higher $\mathrm{pH}$ could indicate greater stress susceptibility of the hens, leading to dark red meat. Activities such as catching, crating, transportation, unloading, and shackling before slaughter produce stress leading to the subsequent variation in meat quality and downgrading of carcasses (Kannan et al., 1997). Extended periods of stress would potentially deplete glycogen reserves, resulting in a higher breast muscle $\mathrm{pH}$. Undesirable environmental conditions (e.g., heat stress, noise, and excessive light, particularly in open houses where birds are harvested during the day) may increase the blood flow to the skin surface as a mechanism to cool the bird. According to Song and King (2015), broilers exposed to antemortem stress factors show relatively higher blood flow from the internal organs to the skin, leading to darkening of the skin tissue. Redirection of blood flow is also caused during exposure to heat stress (Rath et al., 2015; Marchini et al., 2016). Turkeys free to flap on the shackle line showed an acceleration in the initial rate of $\mathrm{pH}$ fall and an increase in CIE $a^{*}$ value compared with those immobilized before death by anesthesia (Froning et al., 1978). Reis and Wooten (1970) noticed that blood flow was 3 times higher in red muscles (which also had higher Mb levels) than in white skeletal muscles. The intense red coloration of the meat may be associated with the increase in pigments, owing to higher blood inflow as a consequence of stress and struggle (Ngoka and Froning, 1982). A higher ultimate $\mathrm{pH}$ may protect $\mathrm{Mb}$ and $\mathrm{Hb}$ from denaturation, resulting in darker colored red meat (Schoenbeck et al., 1998). Therefore, the darker red appearance of hen carcasses may be related to the presence of an increased percentage of $\mathrm{Hb}$ compared with less stressed birds.

A second hypothesis is related to the effectiveness of exsanguination between hens and meat-type pheasants. If bleeding of hens is less effective than meat-type pheasants, some residual blood is trapped inside the veins and arteries within the skin and the muscles, resulting in the higher levels of $\mathrm{Hb}$ in hen carcasses. Although the majority of blood in food animals may be removed by bleeding at slaughter, Kotula and Helbacka (1966) found that small birds have greater proportionate blood volumes than large birds. These authors noted that the blood volumes in chickens weighing $1.0,1.5,2.0,2.5$, and $3.0 \mathrm{~kg}$ were $11.6 \%$, $8.9 \%, 7.3 \%, 7.3 \%$, and $7.4 \%$ of body weight, respectively. About $50 \%$ of total blood volume was retained in the carcasses after slaughter. Furthermore, pigments other than $\mathrm{Mb}$ (e.g., $\mathrm{Hb}$ and cytochrome) are more associated with the color of poultry and fish than with the color of livestock animals and only contribute to meat color attributes to a lesser extent (Suman and 
Joseph, 2013). This residual blood may cause the skin of the carcass or neck to become cherry red to purple (USDA/FSIS, 2009).

A third hypothesis is associated with the scalding and freezing process. The hen skin had greater moisture and protein content, which was likely related to having less fat in it. The differences in chemical composition are attributed not only to the differences in production practices, genetics, and intensity of fattening but also to the age of the birds (Kotowicz et al., 2012). The alteration in the outer layer of skin upon scalding at $60^{\circ} \mathrm{C}$ may lead to the dark appearance of the carcasses upon freezing, probably owing to increased transparency of the skin (Klose and Pool, 1954). The changes in the physical and chemical properties (e.g., protein, fat, collagen, proteoglycans) of poultry skin may result in skin discoloration or cause the underlying muscle to be more visible through the skin during processing (e.g., scalding, freezing; Kafri et al., 1986). Some previous studies have found that the structural integrity of the collagen in the skin may be affected by high scalding temperatures (Smith et al., 1977), and freezing can increase the transparency of the skin (Klose and Pool, 1954). The high amount of moisture within the skin also likely plays a role in the increased transparency of the dark breast muscle. During freezing, ice crystals are formed, resulting in a more transparent surface and darker appearance of the surface of the frozen carcass (Galobart and Moran, 2004). Thus, a major part of the darkening may be related to the translucency of the skin, while the remainder may be associated with the surface layer of the flesh (Lyon and Cason, 1995).

\section{Conclusions}

The results of the current study reveal that hen carcasses had higher red pigmentation and exhibited significantly higher $\mathrm{pH}$ values, redness, and $\mathrm{Mb} / \mathrm{Hb}$ levels than the meat-type pheasants. However, neither genetic nor production practice differences appeared to cause any alterations in the muscle fiber type that would help explain differences in carcass redness. The more intense red appearance may be related to the stress susceptibility of the hens and greater residual $\mathrm{Hb}$. It would be important to understand the factors that affect the changes in the chemical and physical properties of collagen, leading to skin transparency upon freezing. Future studies should consider an understanding of the effects of differences in skin $\mathrm{pH}$ and scalding variations on the physicochemical properties of collagen.

\section{Acknowledgments}

The authors would like to thank MacFarlane Pheasants Incorporated for providing the funding for this research and donating the pheasants. A special thanks to Ryan George at MacFarlane Pheasants for coordinating arrangements between the live production facilities and the processing plant. Thanks are also extended to Twin Cities Pack Incorporated for harvesting the pheasants and allowing access into their facility.

\section{Literature Cited}

AOAC. 2005. Official methods of analysis. 18th ed. AOAC, Gaithersburg, MD.

AOAC. 2011. Official methods of analysis. 18th ed. AOAC, Gaithersburg, MD.

Brooke, M. H., and K. K. Kaiser. 1970. Three myosin adenosine triphosphatase systems: the nature of their $\mathrm{pH}$ lability and sulfhydryl dependence. J. Histochem. Cytochem. 18:670-672. https://doi.org/10.1177/18.9.670.

Choi, Y. S., D. J. Han, J. H. Choi, K. E. Hwang, D. H. Song, H. W. Kim, Y. B. Kim, and C. J. Kim. 2016. Effect of chicken skin on the quality characteristics of semi-dried restructured jerky. Poultry Sci. 95:1198-1204. https://doi.org/10.3382/ps/pew015.

Demirok, E., G. Veluz, W. V. Stuyvenberg, M. P. Castaneda, A. Byrd, and C. Z. Alvarado. 2013. Quality and safety of broiler meat in various chilling systems. Poultry Sci. 92:1117-1126. https://doi.org/10.3382/ps.2012-02493.

Faustman, C., and A. L. Phillips. 2001. Measurement of discoloration in fresh meat. In: S. J. Schwartz, editor, Current protocol in food analytical chemistry. John Wiley and Sons Inc., New York, NY. p. F3.3.1-F3.3.13. https://doi.org/10.1002/ 0471142913.faf0303s00.

Fletcher, D. L. 1989. Factors influencing pigmentation in poultry. Critical Reviews in Poultry Biology. 2:149-170.

Franco, D., and J. M. Lorenzo. 2013. Meat quality and nutritional composition of pheasants (Phasianus colchicus) reared in an extensive system. Brit. Poultry Sci. 54:594-602. https://doi. org/10.1080/00071668.2013.828195.

Froning, G. W., A. S. Babji, and F. B. Mather. 1978. The effect of preslaughter temperature, stress, struggle and anesthetization on color and textural characteristics of turkey muscle. Poultry Sci. 57:630-633. https://doi.org/10.3382/ps.0570630.

Galobart, J., and E. T. Moran. 2004. Freeze-thaw and cooking effects on broiler breast fillets with extreme initial L* values. Poultry Sci. 83:2093-2097. https://doi.org/10.1093/ps/83.12. 2093.

Hofbauer, P., F. M. Smulders, M. Vodnansky, P. Paulsen, and W. R. El-Ghareeb. 2010. A note on meat quality traits of pheasants (Phasianus colchicus). Eur. J. Wildlife Res. 56:809-813.

Huezo, R., D. P. Smith, J. K. Northcutt, and D. L. Fletcher. 2007. Effect of immersion or dry air chilling on broiler carcass moisture retention and breast fillet functionality. J. Appl. Poultry Res. 16:438-447. https://doi.org/10.1093/japr/16. 3.438 . 
Jeong, J. Y., K. K. Janardhanan, A. M. Booren, D. M. Karcher, and I. S. Kang. 2011. Moisture content, processing yield, and surface color of broiler carcasses chilled by water, air, or evaporative air. Poultry Sci. 90:687-693. https://doi.org/10.3382/ ps.2010-00980.

Kafri, I., B. S. Jortner, and J. A. Cherry. 1986. Skin breaking strength in broilers: Relationship with skin thickness. Poultry Sci. 65:971-978. https://doi.org/10.3382/ps.0650971.

Kannan, G., J. L. Heath, C. J. Wabeck, and J. A. Mench. 1997. Shackling of broilers: Effects on stress responses and breast meat quality. Brit. Poultry Sci. 38:323-332. https://doi.org/ 10.1080/00071669708417998.

Klose, A. A., and M. F. Pool. 1954. Effect of scalding temperature on quality of stored frozen turkeys. Poultry Sci. 33:280-289. https://doi.org/10.3382/ps.0330280.

Kotowicz, M., K. Lachowicz, S. Lisiecki, M. Szczygielski, and A. Zych. 2012. Characteristics of common pheasant (Phasianus colchicus) meat. Eur. Poultry Sci. 76:270-276.

Kotula, A. W., and N. V. Helbacka. 1966. Blood retained by chicken carcasses and cut-up parts as influenced by slaughter method. Poultry Sci. 45:404-410. https://doi.org/10.3382/ps.0450404.

Libera, L. D., and E. Carpene. 1997. Myosin heavy and light chains and myosin light chain kinase in skeletal and smooth muscle of some wild avian species. Comp. Biochem. Physiol. 116B:4550. https://doi.org/10.1016/S0305-0491(96)00192-7.

Lind, A., and D. Kernell. 1991. Myofibrillar ATPase histochemistry of rat skeletal muscles: a two-dimensional quantitative approach. J. Histochem. Cytochem. 39:589-597. https://doi. org/10.1177/39.5.1826695.

Lyon, C. E., and J. A. Cason. 1995. Effect of water chilling on objective color of bruised and unbruised broiler tissue. Poultry Sci. 74:1894-1899. https://doi.org/10.3382/ps.0741894.

Mancini, R. A., and M. C. Hunt. 2005. Current research in meat color. Meat Sci. 71:100-121. https://doi.org/10.1016/j.meatsci. 2005.03.003.

Marchini, C. F., M. B. Café, E. G. Araújo, and M. R. Nascimento. 2016. Physiology, cell dynamics of small intestinal mucosa, and performance of broiler chickens under heat stress: A review. Rev. Colomb. Cienc. Pec. 29:159-168. https://doi. org/10.17533/udea.rccp.v29n3a01.

Mir, N. A., A. Rafiq, F. Kumar, V. Singh, and V. Shukla. 2017. Determinants of broiler chicken meat quality and factors affecting them: A review. J. Food Sci. Tech. Mys. 54:29973009. https://doi.org/10.1007/s13197-017-2789-z.

Ngoka, D. A., and G. W. Froning. 1982. Effect of free struggle and preslaughter excitement on color of turkey breast muscles. Poultry Sci. 61:2291-2293. https://doi.org/10. 3382/ps.0612291.

Petracci, M., and D. L. Fletcher. 2002. Broiler skin and meat color changes during storage. Poultry Sci. 81:1589-1597. https:// doi.org/10.1093/ps/81.10.1589.

Rath, P. R., N. C. Behura, S. P. Sahoo, P. Panda, K. D. Mandal, and P. N. Panigrahi. 2015. Amelioration of heat stress for poultry welfare: A strategic approach. International Journal of Livestock Research. 5:1-9. https://doi.org/10.5455/ijlr. 20150330093915.

Reis, D. J., and G. F. Wooten. 1970. The relationship of blood flow to myoglobin, capillary density, and twitch characteristics in red and white skeletal muscle in cat. J. Physiol.-Paris. 210:121135. https://doi.org/10.1113/jphysiol.1970.sp009199.

Roy, S., L. Pantanowitz, M. Amin, R. R. Seethala, A. Ishiaque, S. A. Yousem, A. V. Parwami, I. Cucoranu, and J. Douglas. 2014. Smart-phone adapters for digital photomicrography. Journal of Pathology Informatics. 5:24. https://doi.org/10. 4103/2153-3539.137728.

Sams, A. R., and S. R. Mckee. 2010. First processing: Slaughter through chilling. In: C. M. Owens, C. Z. Alvarado, and A. R. Sams, editors, Poultry meat processing. 2nd ed. CRC Press, Boca Raton, FL. p. 25-49.

Saxton, A. M. 1998. A macro for converting mean separation output to letter groupings in Proc Mixed. Proceedings of the 23rd Annual SAS Users Group International Conference, Nashville, TN, March 22-25. pp. 1243-1246.

Schoenbeck, M. K., D. H. Ropf, M. C. Hunt, J. S. Pontius, S. L. Stroda, and S. Hawthorne. 1998. The effect of $\mathrm{pH}$, myoglobin form and endpoint temperature on cooked ground beef color. 51 st Annual Reciprocal Meat Conference (RMC), Storrs, CT, 28 June-1 July. 51:186-187.

Smith, T. W., J. R. Couch, R. L. Garrett, and C. R. Creger. 1977. The effect of sex, dietary energy, meat protein, ascorbic acid and iron on broiler skin collagen. Poultry Sci. 56:1216-1220. https://doi.org/10.3382/ps.0561216.

Song, D. J., and A. J. King. 2015. Effects of heat stress on broiler meat quality. World Poultry Sci. J. 71:701-709. https://doi. org/10.1017/S0043933915002421.

Stoker, H. S. 2013. Protein structure and the color of meat. In: General, organic, and biological chemistry. 6th ed. Cengage Learning, Belmont, CA. p. 738.

Straková, E., P. Suchý, K. Karásková, M. Jámbor, and P. Navrátil. 2011. Comparison of nutritional values of pheasant and broiler chicken meats. Acta Vet. Brno. 80:373-377. https:// doi.org/10.2754/avb201180040373.

Suman, S. P., and P. Joseph. 2013. Myoglobin chemistry and meat color. Annu. Rev. Food Sci. T. 4:79-99. https://doi.org/10. 1146/annurev-food-030212-182623.

USDA/FSIS. 2009. Ante-mortem and post-mortem poultry inspection. USDA Food Safety and Inspection Service, Washington, DC.

Ve erek, V., P. Suchý, E. Straková, and F. Vitula. 2005. Chemical composition of breast and thigh muscles in fattened pheasant poults. Krmiva. 47:119-125.

Warris, P. 1979. The extraction of haem pigments from fresh meat. Int. J. Food Sci. Tech. 14:75-80. https://doi.org/10.1111/j. 1365-2621.1979.tb00849.x.

Welch Jr, K. C., and D. L. Altshuler. 2009. Fiber type homogeneity of the flight musculature in small birds. Comp. Biochem. Phys. B. 152:324-331. https://doi.org/10.1016/j. cbpb.2008.12.013.

Wideman, N., C. A. O'Bryan, and P. G. Crandall. 2016. Factors affecting poultry meat colour and consumer preferences-A review. World Poultry Sci. J. 72:353-366. https://doi.org/ $10.1017 / \mathrm{s} 0043933916000015$.

Wittenberg, J. B., and B. A. Wittenberg. 2003. Myoglobin function reassessed. J. Exp. Biol. 206:2011-2020. https://doi.org/10. 1242/jeb.00243. 